

RESEARCH ARTICLE

\title{
COMPARISON ANALYSIS OF HEMODIALYSIS UNIT PROFITABILITY BASED ON HOSPITAL RATES, UNIT COST AND INDONESIA CASE BASE GROUPS USING REALIST EVALUATION ANALYSIS AT SILOAM HOSPITALS BALIKPAPAN INDONESIA IN 2018.
}

\author{
Anneke Holly ${ }^{1}$, Alimin Maidin ${ }^{2}$ and Syamsuddin ${ }^{3}$. \\ 1. Master of Hospital Administration Management, Hasanuddin University, Indonesia. \\ 2. Public Health Faculty, Hasanuddin University, Indonesia. \\ 3. Economics and Business Faculty, Hasanuddin University, Indonesia.
}

\section{Manuscript Info}

……………………

\section{Manuscript History}

Received: 10 February 2019

Final Accepted: 12 March 2019

Published: April 2019

Key words:-

Profitability, hospital rates, hospital unit costs, INA-CBGs, RVU, realist evaluation

\begin{abstract}
This study aims to analyze the comparison of hemodialysis profitability based on hospital rates, unit costs, and Indonesia Case Base Groups (INA-CBGs) and evaluate the implementation of INA-CBGS tariff for hemodialysis.

The object in this study was Hemodialysis Unit at Siloam Hospitals Balikpapan (SHBP). This type of research used the mix-methods method with a cross-sectional approach and case study. Primary data were obtained from in-depth interviews with structural and functional staff related to hemodialysis unit. Secondary data were obtained in the form of financial data for hemodialysis measures in 2018. Quantitative analysis was carried out to obtain unit cost values and comparison of the profitability of each tariff. Realist evaluation analysis was used to evaluate the implementation of INA-CBGs rates for hemodialysis.

The results of the study showed that (1) the calculations of unit cost using Relative Value Units (RVU) method of both hemodialysis in SHBP was greater than the hospital unit cost; (2) The tariff calculation using RVU method with a margin of $20 \%$ was found that the hospital and INA-CBGs rates for both hemodialysis were smaller; (3) The calculation of both profitability hospital rates and INA-CBGs rates on the unit cost of the RVU method on both hemodialysis indicated that hospitals experienced losses from both hemodialysis; (4) Hemodialysis Standard Operating Procedure (SOP) and Clinical Pathway (CP) were already available and applied in hospitals. (5) Human resources and the amount of hemodialysis machines in the hemodialysis unit in SHBP were still lacking.
\end{abstract}

Copy Right, IJAR, 2019,. All rights reserved.

\section{Introduction:-}

Hospital is a very complex business entity that must continue to change in order to survive and develop according to the needs of the community. To be able to survive and develop, the hospital requires substantial funds. Management and determination of hospital rates must be carried out efficiently and effectively (Bruen, 2016).

Corresponding Author:-Anneke Holly.

Address:-Master of Hospital Administration Management, Hasanuddin University, Indonesia. 
Since January 1, 2014, Indonesia has entered the era of National Health Insurance (JKN). At the time of entering the JKN era, the payment system in the JKN program was implemented in the form of standard service tariffs based on the service tariff system which is grouped on the same diagnosis known as the Indonesia Case Base Groups (INACBGs) rates.

Payment systems with service tariff determination by Badan Penyelenggara Jaminan Kesehatan (BPJS) are often considered not in accordance with the service rates set by the Hospital so that it affects the services provided. JKN service rates cannot yet be used to cover facility investment, relatively high salary and operational needs in private hospitals. Therefore, the RS seeks to overcome the financing gap by implementing service quota for JKN patients, limiting service time, asking patients to repeatedly come to the hospital or even asking for a deposit or paying for the difference in services obtained.

According to the Central Statistics Agency (BPS), the total population of Indonesia in 2018 was 265,015,300 people with a male life expectancy of 69.16 years and a woman's life expectancy was 73.06 years. At that age, the function of the organs of the human body has begun to decline, making it vulnerable to various serious diseases. One of the many degenerative diseases that are suffered is kidney failure which requires large funding in order to survive. The harder the kidneys work, the kidney health can decrease so that a person must undergo medical action in the form of dialysis. Dialysis or hemodialysis is done by using a machine that will filter out poisons in the body and then remove them. The frequency is done 2-3 times a week (Pudji \& Susalit, 2009; Solikhah, 2011).

Based on data from the Indonesian Renal Registry (IRR) in 2016 there were 52,835 hemodialysis actions with 25,446 new patients. In 2017 there was an increase of 77,892 patients undergoing hemodialysis therapy with 30,831 new patients (PERNEFRI, 2018). The number of patients with kidney disease who require hemodialysis therapy increases every year.

The cost of dialysis treatment is very large, with an estimated cost per patient per year for hemodialysis is more than 12 billion. Because of the high cost of per capita expenditure on health care and the cost of hemodialysis in lower middle income countries, hemodialysis treatment is a priority for the government. Research shows that the cost of hemodialysis increases every year even faster than domestic products in Japan (Sawada \& Kawahara, 2014).

In the treatment of patients with chronic kidney failure undergoing hemodialysis therapy there are often differences in the calculation of hospital rates that are greater than the rates set by the INA-CBGs. These tariff differences should not be borne by patients in accordance with the Ministry of Health Regulation of the Republic of Indonesia in 2014 (Permenkes RI, 2014). If this is allowed to continue it will cause harm to the hospital. Because the financing of hemodialysis treatment is very large, it is necessary to do research to calculate all the financing components in the hemodialysis action.

Several studies comparing hospital rates with INA-CBGs rates have been carried out in various cases, namely in the analysis of the financing of fracture cases (Munawaroh \& Andayani, 2014), cases of diabetes mellitus (Islam and Rusdi, 2014; Fitri et al., 2015), stroke cases (Muslimah et al., 2017) found that there were differences in INA-CBGs rates from BPJS and hospital rates that were not sufficient to finance patient care.

Some studies that analyze the financing of patients undergoing hemodialysis therapy such as research on the amount of hemodialysis costs indicate that the high total costs required by patients undergoing hemodialysis at home (Komenda et al., 2010), research on estimated dialysis costs by the dialysis procedure itself (Icks et al., 2010). Research with similar findings was also conducted in Cameroon (Halle et al., 2017). Research articles conducted in low- and middle-income countries show that financing of hemodialysis therapy is very large (Mushi et al., 2015), the findings of the same study conducted in Tanzania found that the cost of hemodialysis is very large for less developed countries (Mushi et al ., 2015). Other studies in Saudi Arabia suggest that the total cost of hemodialysis is lower compared to other industrialized countries with high service quality standards (Saran \& Sabry, 2012).

Research on the analysis of the cost of illness of Chronic Kidney Disease (CKD) with hemodialysis in outpatients found that there were significant differences in total medical costs directly dependent on several factors (Fauziah et al., 2015). Analysis of overall overall costs incurred by the health system per session of hemodialysis is higher than the funding issued by the health system in India (Kaur et al., 2018), analysis of hemodialysis financing in private hospitals in Turkey shows that the cost per unit of hemodialysis treatment the high price of the treatment unit was 
replaced by the government so that the income earned became less and resulted in the closure of private hemodialysis centers (Tatar et al., 2013).

Research on the analysis of the costs of chronic kidney disease in JKN patients hospitalized shows that the total funding depends on the class of care, severity, investigation and treatment provided (Nugraheni et al., 2016). Research in Denmark shows that kidney transplants are more cost-effective than dialysis (Elgaard et al., 2014). To reduce funding for hemodialysis, alternative treatments for patients with chronic renal failure are Continuous Ambulatory Peritoneal Dialysis (CAPD) or by conducting kidney transplants (Widiana, 2018).

Al-Maidin et al. (2014) found that the tariff setting using RVU with the DDIII approach was appropriately applied to the poor beneficiaries through the Community Health Insurance program or the tariff applied in the INA-CBG payment system having a CRR value for UC DDIII approaching 100\%. Azalea et al. (2016) found that not all hospital tariffs differ significantly from the rates of INA-CBGs. The biggest cost component in the operative group is the cost of operative medical action of $29.39 \%$ of the total cost and the largest non-operative group at the cost of medical support services is $27.12 \%$ of the total cost. Factors that influence the cost of treating chronic kidney patients hospitalized with hemodialysis are comorbid, HD frequency and LOS.

Aditia, Alimin \& Sudirman (2015) found that rates for several disease diagnoses that received wound care in Dr. Tadjuddin Chalid Hospital Makassar were based on Unit I costs compared to hospital rates, the magnitude of the comparison was 18-29\% and the INA-CBGs rates were 23-35\%, the diagnosis rate is based on unit cost II, compared to hospital rates of $19-30 \%$ and with INA-CBGs rates of between $25-39 \%$ while the diagnosis rates are based on unit cost III compared to hospital rates ranging from $97139 \%$ and with INA-CBGs rates of between 118 $197 \%$.

Other research in Iran found different results with the studies previously stated, where financing of hemodialysis in Iran is cheaper than other developing countries (Rezapoor et al., 2012). Calculation of financing analysis from dialysis units conducted at educational hospitals in India shows that the profits obtained are very small, which is equal to $5.67 \%$ of total financing (Ashwini \& Gomes, 2012). Research on the analysis of financing for outpatients undergoing hemodialysis therapy has not been widely carried out.

\section{Theoretical Concept:- \\ Hospital}

The definition of a hospital is an integral part of a social and health organization with the function of providing comprehensive, curative and preventive services to the community and is a training center for health workers and medical research centers (WHO, 2017). According to Undang-Undang No. 44 Tahun 2009, a hospital is a health care institution that organizes individual health services in a comprehensive manner that provides inpatient, outpatient and emergency services.

\section{Tariff}

Tariff is the value of a service determined by a measure of money based on the consideration that with the value of money a company is willing to provide services to its customers (Gani, 1995; Laksono, 2006). Tariff is the value of an analysis of hospital services with a sum of money where based on that value the hospital is willing to provide services to patients (Republic of Indonesia Presidential Regulation, 1992)

\section{INA-CBGs Rates}

INA-CBGs is a system of determining the standard rates used by hospitals as a reference for claims costs to the government carried out by the BPJS health. The pricing of INA-CBGs in the JKN program refers to financing data of 137 hospitals consisting of government hospitals and private hospitals with approximately six million coding cases of disease. The financing amount of INA-CBGs is influenced by the main diagnosis, secondary diagnosis, complications, disease severity and type of action. The medical components that are included in the INA-CBGs tariff calculation consist of doctor consultation, investigation, national formulary drugs, consumable medical materials and equipment, treatment rooms and other costs related to patient health services. The INA-CBGs system cost calculation method is determined by several important data such as disease group codes, outpatient diagnoses without calculating the number of days of treatment, regional locations of hospitals and hospital classes. (Asih, 2014) 


\section{Hemodialysis}

Hemodialysis is a type of kidney replacement therapy that is carried out by flowing blood into an artificial kidney tube (dializer) which consists of two separate compartments (Pudji \& Susalit, 2009). Hemodialysis is the most commonly used method for treating advanced and permanent kidney failure (National Institute of Diabetes and Digestive and Kidney Diseases, 2009).

\section{Unit cost}

Total costs (TC) consist of fixed costs, semivariable costs and variable costs. Fixed cost is a part of total costs that do not change even though the number of movers changes in the relevant range. Fixed costs include many indirect costs such as facility costs (depreciation or rent, insurance, factory building taxes, etc.), salaries of production providers, and other supporting costs that do not change because of the number of units produced (Blocher et al. , 2007). Semivariable costs are the actual costs for operating investment goods but the relative size that has no effect on the amount of production included in this classification is the cost of permanent employee salaries (Rusli, 2017). Variable cost is a cost whose amount is influenced by the amount of production such as the cost of syringes in outpatient services (Rusli, 2017). Variable costs are changes in TC that are associated with each change in the amount (volume) of output (Hansen \& Mowen, 2009).

Unit cost is the amount of costs related to the unit produced divided by the number of units produced. To get information about unit costs, a definition of product costs, measurement of costs and costs is needed. From the explanation above, it can be formulated as follows:

\section{Customer Profitability Analysis}

CPA is the analysis and reporting of revenues earned from customers and costs incurred to obtain these revenues (Horngren et al., 2015). CPA provides information on financing and income from the sales process so that companies can analyze sales made right to provide profits for the company (Faeq, 2018).

According to Supriyono, to obtain optimal profits, it is necessary to know the amount of costs incurred for customers including marketing costs (Supriyono, 1987). CPA based on Hilton, Maher and Selto is done by analyzing all types of customers into the customer profitability statement. The CPA method according to Hilton is more accurate to find out the actual costs. The steps resemble the steps of the method according to Supriyono, the difference is the distribution of costs based on their functions.

\section{Realist Evaluation Analysis}

This realist evaluation is a theory-based approach and uses realism to see the success or failure of a program (Pawson R., 1997).

\section{Research Method:-}

The type of research used is mix methods using a cross sectional study and case study design. This research was conducted at Siloam Hospitals Balikpapan. Data collection is carried out with in-depth interviews with parties related to financial data and through literature with reports and documents relating to the finances of hemodialysis units at Siloam Hospitals Balikpapan. The population is structural staff and functional staff related to the Hemodialysis Siloam Hospitals Balikpapan Unit. A sample of 5 informants were selected for in-depth interviews and were willing to take part in this study by signing the informant's consent sheet, as well as financial data and financing of outpatient hemodialysis measures in 2018. Unit cost data is processed using unit cost calculations using the Relative Value Unit (RVU) method using the Microsoft Excell 2013 for Windows program. To assess the implementation program the rate of hemodialysis action based on INA-CBGs was analyzed using the realist evaluation method.

\section{Results and Discussions:- \\ Unit Cost Calculation}

The results of calculating the total cost of hemodialysis and its support during 2018. The total fixed costs are Rp. $567,898,907$, the total amount of semi-variable costs is Rp. 1,848,522,608 and the total amount of non-fixed costs is Rp. 6,929,675,500.

The calculation of tariffs per type of action using the RVU method. The tariff for single-use hemodialysis is Rp. $2,519,349$ while for hemodialysis re-use is Rp. 2,428,154. 


\section{Calculation of Customer Profitability Analysis (CPA)}

The calculation CPA of hospital and INA-CBGs rates based on the unit cost calculations using RVU Method for both hemodialysis proves that in determining the price between hospital rates and INA-CBGs rates shows a loss for the hospital. This shows that hospital suffers from both hemodialysis in both BPJS patients and general patients.

\begin{tabular}{|c|c|c|c|c|}
\hline \multirow{2}{*}{ Customer Profit } & \multicolumn{2}{|c|}{ Single Use } & \multicolumn{2}{|c|}{ Re-Use } \\
\hline & $\begin{array}{c}\text { Hospital Rates } \\
\text { (Rupiahs) }\end{array}$ & $\begin{array}{l}\text { INA-CBGs } \\
\text { (Rupiahs) }\end{array}$ & $\begin{array}{c}\text { Hospital Rates } \\
\text { (Rupiahs) }\end{array}$ & $\begin{array}{l}\text { INA-CBGs } \\
\text { (Rupiahs) }\end{array}$ \\
\hline Sales & $1,177,000$ & 994,400 & 910,000 & 994,400 \\
\hline Hospital Unit Cost & $1,574,593$ & $1,574,593$ & $1,517,596$ & $1,517,596$ \\
\hline Margin contribution & $-397,593$ & $-580,193$ & $-607,596$ & $-523,196$ \\
\hline Margin contribution ratio & $-34 \%$ & $-58 \%$ & $-67 \%$ & $-53 \%$ \\
\hline \multicolumn{5}{|l|}{ Operating costs } \\
\hline Employee salary & 107,454 & 107,454 & 107,454 & 107,454 \\
\hline Sales Administration & 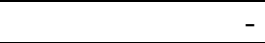 & - & - & - \\
\hline Total Sales Cost & $30,000.00$ & - & $30,000.00$ & - \\
\hline Employee salary & 137,454 & 107,454 & 137,454 & 107,454 \\
\hline \multicolumn{5}{|l|}{ Marketing Management } \\
\hline Total Marketing Costs & 4,953 & 4,953 & 4,953 & 4,953 \\
\hline \multicolumn{5}{|l|}{ Other operating costs } \\
\hline Development costs & 9,906 & 9,906 & 9,906 & 9,906 \\
\hline Administration and general fee & 30,000 & 30,000 & 30,000 & 30,000 \\
\hline Total operating costs & 39,906 & - & 39,906 & \\
\hline Operating income & $-579,907$ & $-692,600$ & $-789,910$ & $-635,603$ \\
\hline Return on sales & $-49 \%$ & $-70 \%$ & $-87 \%$ & $-64 \%$ \\
\hline
\end{tabular}

\section{Assessment of INA-CBGs Tariff Program}

In the results of in-depth interviews the informants' understanding of the financing of hemodialysis measures showed that most informants explained and knew the definitions and benefits of hemodialysis in hospitals, knowing the availability of Standard Operating Procedures (SOPs) that were used as guidelines for implementing hospital hemodialysis measures according to Head office standards (HO), the funding for implementing hospital hemodialysis is divided according to the type of action and status of the patient, the financing calculation for the hemodialysis RS is determined by $\mathrm{HO}$, and there are still some obstacles in implementing hemodialysis in the hospital. The data analysis with the Context - Mechanism - Outcome (C-M-O) configuration from the results of indepth interviews.

\section{Discussion:-}

In this study it can be seen that the hospital unit cost calculation shows a lower value compared to the unit cost calculation of the RVU method which influences the hospital income. RVU is the multiplication of the weights obtained by the output of the type of action in the hemodialysis section. The amount of RVU value is strongly influenced by the amount of output and the amount of weight, where the higher the output value and the weight, the higher the RVU value. The results of the study show the components of material costs, employee salaries, and equipment that affect the amount of the total costs that will be used to find the weight of each action. The action that has the largest total cost is single-use hemodialysis and the smallest is the hemodialysis re-use. The procedure for the hemodialysis machine itself will certainly produce different costs between the use of both machines. Procedure for re-use has lower consumables costs than single-use. In single-use the dialiser component (loop loop) is used once for each action in one patient, while in the re-use diapap the loop can be used to $4 \mathrm{x}$ actions in the same patient. So that there will be a difference in the price of hemodialysis.

In single-use hemodialysis, the comparison between hospital rates and unit cost rates with the RVU method has a loss of Rp. 1,342,349. Whereas the comparison between the INA-CBGs rates on unit costs and the RVU method shows a loss of Rp. 1,524,949. The difference in hospital unit cost calculation with the unit cost of the RVU method is Rp. 619,735. In hemodialysis re-use, the comparison between hospital rates and unit cost rates with the RVU method has a loss of Rp. 1,518,154. Whereas the comparison between the INA-CBGs rates on unit costs and the RVU method shows a loss of Rp. 1,433,754. The difference in hospital unit cost calculation with the unit cost of the 
RVU method is Rp. 712,707. This shows that in both hemodialysis, there is a difference that must be borne by the hospital on the actual tariff.

Determination of hospital rates must be adjusted to the actual unit cost calculation. The need for assessment and adjustment of some of the tariffs applied in the INA-CBGs system, by approaching the cost of RVU. Knowing the difference that must be borne by the patient on the actual tariff. As well as the hospital needs to reevaluate the existing rates, in order to realize an efficient and effective hospital. The hospital must provide training for human resources to improve competencies and expertise so that in carrying out their duties it can be more effective and efficient and the supporting facilities are only 12 units of hemodialysis machines while patients are increasing every year.

Based on the research conclusions, further research suggestions should be carried out to provide more comprehensive results as follows: (1) Further research is expected to further expand the sample analysis unit or research so that the results of the study can be more generalized. (2) Further research is expected to be able to add or consider other variables that can be used to review which can affect the quality of Hemodialysis Unit Costing. (3) The next researcher needs to consider the timing of the research, the next researcher should better carry out preresearch to enable initial data collection and ensure the research schedule related to the object of the research.

\section{References:-}

1. Aditia, A., Alimin, M. and Sudirman, N. (2015) 'Perbandingan Tarif Berdasarkan Unit Cost Dengan Tarif Rumah Sakit Dan INA-CBGS', JST Kesehatan, 5(2), pp. 111-118.

2. Al-maidin, A. R. M., Noor, N. B. and Pasinringi, S. A. (2014) 'Perbandingan Tarif Tindakan Operasi Berdasarkan Relative Value Unit (RVU), Indonesia Case Based Groups (INA- CBG's) dan Tarif Kolegium', Al-Sihah: Public Health Science Journal, VI(2), pp. 397-409.

3. Ashwini, N. S. and Gomes, L. A. (2012) 'Cost analysis of a dialysis unit at a tertiary care multi specialty teaching hospital', Journal International Medical Sciences Academy, 25(3), pp. 177-178.

4. Asih Eka Putri (2014) Paham BPJS. 2nd edn. Jakarta: Friedrich-Ebert-Stiftung.

5. Azalea, M., Andayani, T. M. and Satibi (2016) 'Inap Dengan Hemodialisis Di Rumah Sakit Cost Analysis of Inpatient Hemodialysis in the Treatment of Chronic', Jurnal Manajemen dan Pelayanan Farmasi, pp. 141-150.

6. Badan Pusat Statistik (2018) 'Statistik Indonesia 2018'.

7. Blocher Ed, Chen Kung, Cokins Gary, L. T. (2007) Manajemen Biaya: Penekanan Strategis. 3rd edn. Edited by Resthi Widyaningrum. Jakarta: Penerbit Salemba Empat.

8. Bruen, L. R. (2016) 'We need to override the digital TCP microchip!', pp. 144-158.

9. Elgaard Jensen, C., Sørensen, P. and Dam Petersen, K. (2014) 'In Denmark kidney transplantation is more costeffective than dialysis', Danish Medical Journal, 61(3), pp. 1-5.

10. Faeq Malallah Mahmood Albalaki, R. J. M. (2018) 'Customer Profitability Analysis, Cost System Purposes and Decision Making Process: A Research Framework', Account and Financial Management Journal, 3(5), pp. 1547-1552.

11. Fauziah, Djoko Wahyono, L. E. B. (2015) 'Cost of Illness Dari Chronic Kidney Disease Dengan Tindakan', Jurnal Manajemen dan Pelayanan Farmasian Pelayanan Farmasi, 5(3), pp. 143-151.

12. Fitri, E., Andayani, T. M. and Suparniati, E. (2015) 'Cost Analysis of Diabetes Melitus', Journal of Management and Pharmacy Practice, 5(1), pp. 61-66.

13. Gani, A. (1995) 'Teori Biaya', in Buku Panduan Analisis Biaya dan Penyesuaian Tarif Pelayanan Kesehatan di Indonesia. Jakarta: FKM UI.

14. Halle, M. P. et al. (2017) 'Cost of care for patients on maintenance haemodyalisis in public facilities in Cameroon', African Journal of Nephrology, 20(1), pp. 230-237.

15. Hansen, Don R., Mowen, M. M. (2009) Managerial Accounting. 8th edn. Jakarta: Penerbit Salemba Empat.

16. Icks, A. et al. (2010) 'Costs of dialysis-a regional population-based analysis', Nephrology Dialysis Transplantation, 25(5), pp. 1647-1652. doi: 10.1093/ndt/gfp672.

17. Islam, Z. and Rusdi, N. K. (2014) 'Analisis Perbedaan Pengobatan Diabetes Melitus Tipe Ii Pada Pasien Bpjs Dan Pasien Umum the Analisys Different of Treatment Diabetes Melitus Type Ii on General Patients and National Health Insurrance Patients (BPJS)', pp. 151-161.

18. Kaur, G. et al. (2018) 'Cost of hemodialysis in a public sector tertiary hospital of India', Clinical Kidney Journal, 11(5), pp. 726-733. doi: 10.1093/ckj/sfx152.

19. Komenda, P. et al. (2010) 'The cost of starting and maintaining a large home hemodialysis program', Kidney International. Elsevier Masson SAS, 77(11), pp. 1039-1045. doi: 10.1038/ki.2010.37. 
20. Laksono Trisnantoro (2006) Memahami Penggunaan Ilmu Ekonomi Dalam Manajemen Rumah Sakit. Yogyakarta: Gajah Mada University Press.

21. Munawaroh, F. and Andayani, T. M. (2014) 'Pembiayaan Kesehatan Berdasar Ina-CBGs Cost Analysis of Bone Fracture Treatment in Determining Health Financing Based on Ina-Cbgs’, pp. 45-54.

22. Mushi, L., Krohn, M. and Flessa, S. (2015) 'Cost of dialysis in Tanzania: evidence from the provider's perspective', Health Economics Review. Health Economics Review, 5(1). doi: 10.1186/s13561-015-0064-4.

23. Mushi, L., Marschall, P. and Fleßa, S. (2015) 'The cost of dialysis in low and middle-income countries: A systematic review', BMC Health Services Research. BMC Health Services Research, 15(1), pp. 1-10. doi: 10.1186/s12913-015-1166-8.

24. Muslimah, Tri Murti Andayani, Rizaldy Pinzon, D. E. (2017) 'Perbandingan Biaya Riil Terhadap Tarif INACBGs Penyakit Stroke Iskemik di RS Bethesda Yogyakarta', Jurnal Manajemen dan Pelayanan Farmasi, 7(2), pp. 105-114.

25. National Institute of Diabetes and Digestive and Kidney Diseases, [NIDDK] (2009) 'Treatment Methods for Kidney Failure : Hemodialysis', National Institutes of Health, pp. 1-11.

26. Nugraheni, D. A. et al. (2016) 'Analisis Biaya Penyakit Ginjal Kronis Pada Pasien Jkn Rawat Inap Di Rumah Sakit Pku Muhammadiyah Yogyakarta’, (4), pp. 2541-474.

27. Pawson R., T. N. (1997) Realistic Evaluation. 1st edn. SAGE Publications Ltd.

28. Permenkes RI (2014) 'Peraturan Menteri Kesehatan Republik Indonesia Nomor 27 Tahun 2014 Tentang Petunjuk Teknis Sistem Indonesian Case Base Groups (INA-CBGs)', in.

29. Permenkes RI (2014) 'Peraturan Menteri Kesehatan Republik Indonesia Nomor 59 Tahun 2014 Tentang Standar Tarif Pelayanan Kesehatan Dalam Penyelenggaraan Program Jaminan Kesehatan’.

30. PERNEFRI (2018) ' 10 th Report Of Indonesian Renal Registry 201710 th Report Of Indonesian Renal Registry 2017'.

31. Perpres RI (1992) 'Undang Undang No . 23 Tentang Kesehatan', (23).

32. Perpres RI (2009) 'Undang-Undang Nomor 40 Tentang Rumah Sakit'.

33. Pudji R, Susalit E, S. (2009) 'Hemodialisis', in Aru W. Sudoyo, Bambang Setiyohadi, Idrus Alwi, Marcellus Simadibrata K., S. S. (ed.) Buku Ajar Ilmu Penyakit Dalam. III. Jakarta: Interna Publishing.

34. Rezapoor, A., Azar, F. E. F. and Safari, H. (2012) 'Cost Analysis of Services Delivered to Patients with EndStage Renal Disease Referring to Bou-Ali-Sina Hospital Affiliated to Qazvin University of Medical Sciences', World Applied Sciences Journal, 18(6), pp. 796-802. doi: 10.5829/idosi.wasj.2012.18.06.645.

35. Ronald Hilton, Michael Maher, F. S. (2004) Cost Management Strategies for Business Decisions. 3rd edn. United States: McGraw-Hill Companies.

36. Rusli, N. T. (2017) 'Analisis Biaya dan Faktor-Faktor Penentu Inefisiensi Layanan Hemodialisis pada Pasien Gagal Ginjal Kronik Rumah Sakit Rk Charitas Palembang Tahun 2016', Jurnal Administrasi Rumah Sakit, 3(3), pp. $158-168$.

37. Saran, K. and Sabry, A. (2012) 'The Cost of Hemodialysis in a Large Hemodialysis Center', Saudi J Kidney Dis Transpl, 23(1), pp. 78-82. doi: 10.4103/1319-2442.91306.

38. Sawada, T. and Kawahara, H. (2014) 'Cost of hemodialysis after coverage by national health insurance in Japan: a sharing experience with Indonesian health reform system', Medical Journal of Indonesia, $23(2)$, p. 122. doi: 10.13181/mji.v23i2.652.

39. Solikhah, P. T. M. (2011) 'Analisa Cost Sharing Perhitungan Tarif Hemodialisis (HD) Masyarakat Miskin di Rumah Sakit Umum PKU Muhammadiyah Unit I Yogyakarta', Kes Mas, 5(3), pp. 162-232.

40. Supriyono (1987) Akuntansi Biaya: Pengumpulan Biaya dan Penentuan Harga Pokok Produk. 2nd edn. Yogyakarta: BPFE Universitas Gajah Mada.

41. Tatar, M., Ergin, G. and Ecder, T. (2013) 'Cost analysis of private hemodialysis centers in turkey', Turkish Nephrology, Dialysis and Transplantation Journal, 22(3), pp. 270-282. doi: 10.5262/tndt.2013.1003.07.

42. WHO (2017) Hospitals in Health Systems. Available at: https://www.who.int/hospitals/en/ (Accessed: 4 April 2019).

43. Widiana, I. G. R. (2018) 'Dialysis treatment in Indonesia: Focus on Bali', IOP Conference Series: Materials Science and Engineering, 434, p. 012334. doi: 10.1088/1757-899X/434/1/01233. 